\title{
COMPARISON BETWEEN ECTODOMAIN AND G2 REGION OF G GLYCOPROTEIN FOR GENOTYPING OF HRSV
}

\author{
Angélica Cristine de Almeida Campos ${ }^{1}$; Edison Luiz Durigon ${ }^{1}$; Andréa Lima Leal ${ }^{1}$; Tereza Souza Silva ${ }^{1}$; Patrícia \\ Alves Ramos Bosso ${ }^{1}$; Claudia Trigo Pedroso Moraes ${ }^{1}$; Danielle Bruna Leal Oliveira ${ }^{1}$; Hildener Nogueira Lima ${ }^{1}$; \\ Sandra Elisabete Vieira ${ }^{2}$; Viviane Fongaro Botosso ${ }^{3}$; Paolo Marinho de Andrade Zanotto ${ }^{1}$; Klaus Eberhard Stewien ${ }^{1}$
}

${ }^{1}$ Instituto de Ciências Biomédicas, Universidade de São Paulo, São Paulo, SP, Brasil; ${ }^{2}$ Hospital Universitário, Universidade de São Paulo, São Paulo, SP, Brasil; ${ }^{3}$ Instituto Butantã, São Paulo, SP, Brasil.

Submitted: August 04, 2006; Returned to authors for corrections: September 19, 2006; Approved: August 03, 2007.

\section{SHORT COMMUNICATION}

\begin{abstract}
The Human Respiratory Syncytial Virus (HRSV), isolated in 1955, is the main cause of hospitalization of babies and infants with respiratory illness. Several studies have been conducted worldwide aiming the development of a safe and effective vaccine against HRSV. The G2 region of glycoprotein G is used as genotyping default. In the present study, we performed a phylogenetic analysis of $\mathrm{G}$ protein and a comparative study between $\mathrm{G} 2$ region and ectodomain of attachment glycoprotein. Fifty-three nasal swab samples from children less than 5 years old and presenting symptoms of acute respiratory illness, assisted at the University Hospital (UH) of University of Sao Paulo (USP) in 2004, were submitted to sequencing by PCR and compared with GenBank sequences. We concluded that the G2 region is adequate for HRSV genotyping.
\end{abstract}

Key words: Human Respiratory Syncytial Virus; G Glycoprotein; G2 Region; Phylogenetic Analysis

The Human respiratory syncytial virus (HRSV) is an enveloped nonsegmented negative-strand RNA virus (family Paramyxoviridae, genus Pneumovirus). HRSV is the main cause of respiratory infections leading to infant hospitalization $(5,14)$. Acute respiratory infections (ARIs) are the commonest cause of morbidity and mortality in children worldwide, and are responsible for about $30 \%$ of deaths in developing countries (12). Outbreaks of respiratory infections caused by HRSV occur yearly and previous infection do not protect against new infections although reinfections with HRSV are usually less severe $(9,10)$. The two major groups of HRSV are classified into group A strains with GA1-GA7 $(21,22)$ and SAA1 $(31)$ genotypes, and group B strains with GB1-GB4 (21) and SAB1-SAB3 (31) genotypes.

Most studies concerning genetic variability and evolution of attachment $G$ protein are based on HRSV A strains $(8,24,37)$, and there is little information available about the genetic diversity and molecular evolution of HRSV B strains $(15,27,29)$. The predominance of HRSV A over HRSV B viruses has been attributed to the higher variability among the HRSV A strains $(21,31)$.

According to Purcell and Fergie (23), the comparison of clinical effects and the different groups and genotypes are hampered by other factors that affect the severity of infection by HRSV, such as prematurity, age of the children, and presence of other pre-existing conditions.

The present study aimed to sequence the glycoprotein $\mathrm{G}$ gene and compare the complete sequencing of ectodomain of gene $\mathrm{G}$ with the $\mathrm{G} 2$ region, in order to identify the existence of differences in HRSV genotyping. Such information provides correct identification of HRSV genotypes, thus contributing to the development of a secure vaccine. Despite isolated more than 50 years ago, the virus is still considered an important agent of respiratory infections and hospital internments. In this scenario, a new vaccine could create new and more efficient options for prevention and treatment of infections caused by HRSV.

\footnotetext{
*Corresponding Author. Mailing address: Instituto de Ciências Biomédicas da Universidade de São Paulo (ICBII-USP). E-mail: camposac@usp.br
} 


\section{Target}

Sequences of 53 Brazilian samples and 89 sequences acquired from GenBank (access number in footnote) were used.

\section{Primers}

Oligonucleotide primers previously described for amplifying the ectodomain of G glycoprotein of HRSV were used $(21,24,36)$.

\section{PCR}

For amplification assays for glycoprotein $\mathrm{G}, 10 \mu \mathrm{l}$ of cDNA were distributed in $0.2 \mathrm{ml}$ tubes containing 10x PCR buffer, 2.5 $\mathrm{mM}$ of $\mathrm{MgCl}_{2}, 1.25 \mathrm{mM}$ of each dNTP, $50 \mathrm{pM}$ of each set primers, 1.25U Taq DNA polymerase (Applied Biosystems) and Ultra pure water for $100 \mu \mathrm{l}$. Thermo cycling was programmed for $96^{\circ} \mathrm{C}$ for $2 \mathrm{~min}, 40$ cycles of $94^{\circ} \mathrm{C}$ for $1 \mathrm{~min}, 57^{\circ} \mathrm{C}$ for $1 \mathrm{~min}$, and $72^{\circ} \mathrm{C}$ for $1 \mathrm{~min}$ for cDNA/DNA amplification; and $7 \mathrm{~min}$ at $72^{\circ} \mathrm{C}$ for final amplicon extension.

\section{Sequence Reaction}

Sequencing assays were performed separately with $2 \mu \mathrm{l}$ of ABI PRISM Dye Terminator Cycle Sequencing Ready Reaction kit (Big Dye version 3.1-Applied Biosystems), and 10-30 ng of PCR product (glycoprotein G), distributed in $0.2 \mathrm{ml}$ tubes containing 5x Save Money buffer, $3.2 \mathrm{pM}$ of each set primers and Ultra pure water for $10 \mu$. Thermo cycling was programmed for $96^{\circ} \mathrm{C}$ for $1 \mathrm{~min}, 25$ cycles of $96^{\circ} \mathrm{C}$ for $15 \mathrm{sec}, 50^{\circ} \mathrm{C}$ for $15 \mathrm{sec}$, and $60^{\circ} \mathrm{C}$ for $4 \mathrm{~min}$ for DNA extension.

\section{Purification of Sequence Reaction}

The sequenced products were purified by precipitation with acetate and ethanol, to remove excess of salts, distributed in the plate of 96 wells containing $10 \mu$ l of formamide Hi-Di (Applied Biosystems), denatured at $90^{\circ} \mathrm{C}$ for $3 \mathrm{~min}$, and cooled on ice. Sequence analysis was performed on an ABI Prism 3100 Genetic Analyzer (Applied Biosystems) using a 50cm capillary with POP$6^{\mathrm{TM}}$ polymer.

\section{Sequence Analysis}

The sequence analysis was carried out using PCR products with previously described primers $(21,24,36)$. The phylogenetic trees were constructed using the PAUP*4.0 program, version Beta, Sinauer Associates, Incorporation, for Power Macintosh and Unix (28) using the Neighborn joining algorithm and heuristic search. Bootstrap values were calculated with 100 replicates (6).

\section{Phylogenetic trees}

The genetic analysis with PAUP* are shown in Fig. 1.

\section{Genotyping of HRSV}

Out of 53 sequenced samples, 18 (34\%) were GA2, 27 (51\%) were GA5, $3(5.5 \%)$ were SAB1, 4 (7.5\%) were SAB3 and $1(2 \%)$ was GB3 with insertion of 60 nucleotides.
The alignments of glycoprotein $\mathrm{G}$ ectodomain and $\mathrm{G} 2$ region indicated that the $\mathrm{G} 2$ region is sufficient enough for genotyping of HRSV. The analysed samples did not show many differences from the genotypes described by Peret $e t$ al., $(21,22)$ and Venter et al. (31). The values of bootstrap were superior to $70 \%$ (calculated with 100 rejoinders) for the verification of the sustentation branches in topologies of the gotten trees (6). As already extensively observed in the literature $(1,11,13,19,21,22,25,34,35)$, the groups A and B cocirculate in outbreaks with the predominance of one over the other. The phylogenetic analysis showed that groups A and B co-circulated in São Paulo city with predominance of group A $(4,16,32)$ in the studied period. The found genotypes GA2 and GA5 (group A), SAB1 and SAB3 (group B), and a additional single sample presenting repetitive insertion of 60 nt to GB3 genotypes (related as BA-like) have also been found in recent studies $(2,3,7,38)$.

\section{ACKNOWLEDGEMENTS}

The authors thank the Brazilian Research Council (CNPq) for financial support and the University Hospital of University of Sao Paulo, Brazil (UH-USP) for providing the samples. We are thankful to Cláudia Filoni for English corrections. This study it is integrant part of the Viral Genetic Diversity Network (VGDN), financed by the Foundation of Support to the Research of the State of São Paulo (FAPESP).

\section{RESUMO}

\section{Comparação entre o ectodomínio e a região G2 da glicoproteína G para genotipagem de HRSV}

O vírus respiratório sincicial humano (HRSV), isolado em 1955, é a principal causa da hospitalização de bebês e crianças pequenas com sintomas de doença respiratória. No mundo inteiro, vários estudos para o desenvolvimento de uma vacina segura e eficiente contra o HRSV têm tido alta prioridade. A região $\mathrm{G} 2$ da glicoproteína $\mathrm{G}$ é usada como padrão para genotipagem do HRSV. Neste estudo, foi realizada a análise filogenética da glicoproteína $\mathrm{G}$ e o estudo comparativo entre a região G2 e o ectodomínio dessa glicoproteína. Cinquenta e três amostras de swab nasal de crianças com menos de cinco anos de idade, apresentando doença respiratória aguda, atendidas no Hospital Universitário (HU) da Universidade de São Paulo durante o ano de 2004, foram submetidas a sequenciamento por PCR e comparadas com sequiências do GenBank. A região G2 mostrou ser adequada para a genotipagem do HRSV.

Palavras chave: Vírus Respiratório Sincicial Humano; Glicoproteína G; Região G2; Análise Filogenética 


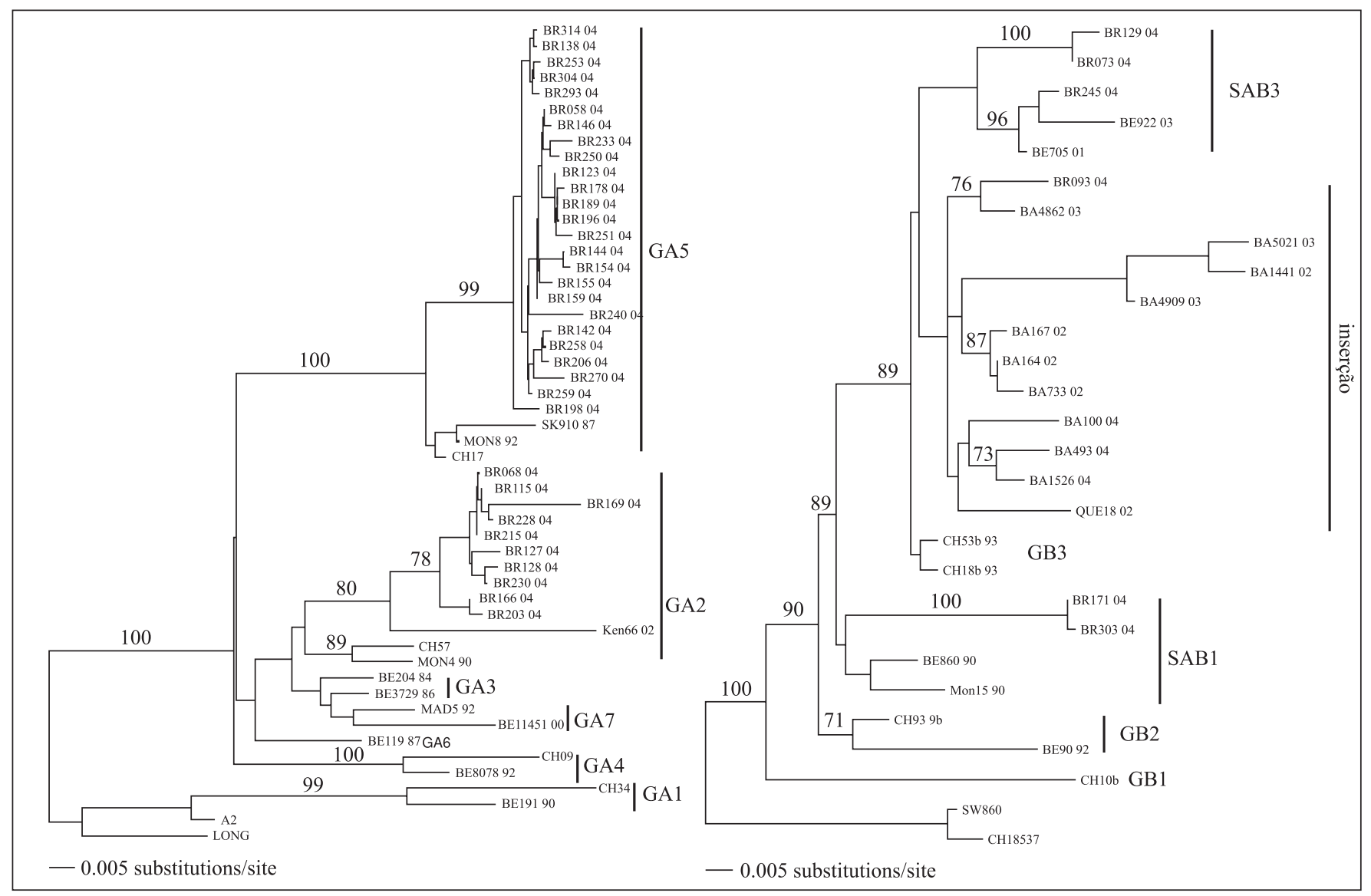

Figure 1. Ecdomain of group A and group B. 7Analized by distance method (Tamura Ney Model) with gamma distribuition (2.6559). Heuristic search find trees.

Footnote: Access number of GenBank X03149, M55633, M17212, M17213,AF065250-AF065255, AF065257, AF065258, AF193304, AY343620,AY343622-AY343626, AY343631,AY343633,AY343640,AY343644-AY343647,AY343650,AY343652-AF343660,AY343554, AY343556-AY343558,AY343561,AY343568,AY343572,AY343573,AY343577,AY343581-AY343584,AY343587,AY343590,AY343592, AY343594,AY343596,AY343597,AY524573,AY524575,AY524581,AY524584,AY524585,AY524593,AY524595,AY524606, AY524607, AY524620,AY524632,AY524635,AY524644,AY524648,AY524652, AY524660,AY524663,Z334112,Z33415,Z33417,Z33419, Z33420, Z33426,Z33430, AY660668, AY660669, AY660671,AY660674,AY660675, AY660677-AY660679, AY660681, AY660683, AY660684, AY751204,AY751206,AY751207,AY751211-AY751213,AY751215,AY751217-AY751219,AY751220,AY751222-AY751224,AY751226, AY751228-AY751233,AY751235,AY751236-AY751239,AY751241-AY751245,AY751247,AY751248,AY751264,AY751087,AY751089, AY751092- AY751094, AY751103, AY751105, AY751107, AY751111, AY7511117-AY751120, AY751122- AY751125, AY751131, AY751136,AY751144,AY751145,AY751148,AY751149,AY751151,AY751153,AY751157-AY751159,AY751162,AY751163,AY751169, AY751172-AY751174,AY751176,AY751179-AY751182,AY751184,AY751186,AY751187,AY751189,AY751191,AY751194-AY751198, AY333361,AY773291, DQ227367,DQ227369, DQ227374,DQ227381,DQ227391,DQ227395

\section{REFERENCES}

1. Anderson, L.J.; Hierholzer, J.C.; Tsou, C.; Hendry, R.M.; Fernie, B.F.; Stone, Y.; McIntosh, K. (1985). Antigenic Characterization of Respiratory Syncytial Virus Strains With Monoclonal Antibodies. $J$. Infect. Dis., 151, 626-633.

2. Arbiza, J.; Delfraro, A.; Frabasile, S. (2005). Molecular epidemiology of human respiratory syncytial vírus in Uruguay: 1985-2001 - a review. Mem. Inst. Oswaldo Cruz, 100(3), 221-30.
3. Blanc, A.; Delfraro, A.; Frabasile, S.; Arbiza, J. (2005). Genotypes of respiratory syncytial vírus group B indentified in Uruguay. Arch. Virol., 150(3), 603-9. (Epub 2004 Oct 11).

4. Bosso, P.A.R.; Candeias, J.M.G.; Paduan, K.S.; Ricchetti, S.M.Q.; Miranda, A.F.M.; Rugolo, L.M.S.S.; Durigon, E.L.; Ventura, A.M. (2004). Human respiratory syncytial virus detection in children admitted at a community hospital in Botucatu, SP, Brazil. Braz. J. Microbiol., 34, 348-351.

5. Collins, P.L.; Chanock, R.M.; Murphy, B.R. (2001). Respiratory syncytial virus. In: Knipe, D.M.; Howley, P.M. Editors. Fields Virology. Philadelphia: Lippincott- Williams and Wilkins, pp 1443-1486. 
6. Felsenstein, J. (1985). Confidence limits on phylogenies: an approach using the bootstrap. Evolution., 39, 783-91.

7. Galiano, M.C.; Palomo, C.; Videla, C.M.; Arbiza, J.; Melero, J.A.; Carballal, G. (2005). Genetic and antigenic variability of human respiratory syncytial vírus (groups A and B) isolated over seven consecutive seasons in Argentina (1995-2001). J. Clin. Microbiol., 43(5), 2266-73.

8. Garcia, O.; Martin, M.; Dopazo, J.; Arbiza, J.; Frabasile, S.; Russi, J.; Hortal, M.; Perez-Brena, P.; Martinez, I.; Garcia-Barreno, B.; Melero, J.A. (1994). Evolutionary pattern of human respiratory syncytial vírus (sub-group A): Cocirculating lineages and correlation of genetic and antigenic changes in the G glycoprotein. J. Virol., 68, 54485459.

9. Glezen, W.P.; Taber, L.H.; Frank, A.L.; Kasel, J.A. (1986). Risk of primary infection and reinfection with respiratory syncytial virus. Am. J. Dis. Child., 140, 543-546.

10. Henderson, F.W.; Collier, A.M.; Clyde, W.A.Jr.; Denny, F.W. (1979). Respiratory-syncytial-virus infections, reinfections and immunity. A prospective, longitudinal study in young children. N. Engl. J. Med., 300, 530-534.

11. Hendry, R.M.; Talis, A.L.; Godfrey, E.; Anderson, L.J.; Fernie, B.F.; McIntosh, K. (1986). Concurrent circulation of antigenically distinct strains of respiratory syncytial virus during community outbreaks. J. Infect. Dis., 153, 291-297.

12. Hinman, A.R. (1998). Global progress in infectious diseases control. Vaccine, 16, 1116-1121.

13. Imaz, M.S.; Sequeira, M.D.; Videla, C.; Veronessi, I.; Cociglio, R.; Zerbini, E.; Carballal, G. (2000). Clinical and Epidemiological Characteristics of Respiratory Syncytial Virus Subgroups A and B Infections in Santa Fe, Argentina. J. Med. Virol., 61, 76-80.

14. Iwane, M.K.; Edwards, K.M.; Szilagyi, P.G.; Walker, F.J.; Griffin, M.R.; Weinberg, G.A.; Coulen, C.; Poehling, K.A.; Shone, L.P.; Balter, S.; Hall, C.B.; Erdman, D.D.; Wooten, K.; Schwartz, B.New Vaccine Surveillance Network. (2004). Population-based surveillance for hospitalizations associated with respiratory syncytial virus, influenza virus, and parainfluenza viruses among young children. Pediatrics, 113, 1758-64.

15. Kamasaki, H.; Tsutsumi, H.; Seki, K.; Chiba, S. (2001). Genetic variability of respiratory syncytial vírus subgroup B strain isolated during the last 20 years from the same region in Japan: existence of time-dependent linear genetic drifts. Archl. Virol., 146, 457-466.

16. Lukic-Grlic, A.; Cane, P.A.; Bace, A.; Pringle, C.R.; MlinaricGalinovic, G.; Popow-Kraupp, T. (1998). Antigenic and genomic diversity of central European respiratory syncytial virus strains. Arch. Virol., 143(7), 1441-7.

17. Mazzulli, T.; Peret, T.C.; McGeer, A.; Cann, D.; MacDonald, K.S.; Chua, R.; Erdman, D.D.; Anderson, L.J. (1999). Molecular characterization of a nosocomial outbreak of human respiratory syncytial virus on an adult leukemia/lymphoma ward. J. Infect. Dis., 180(5), 1686-9.

18. Melero, J.A.; Garcia-Barreno, B.; Martinez, I.; Pringle, C.R.; Cane, P.A. (1997). Antigenic structure, evolution and immunobiology of human respiratory syncytial virus attachment (G) protein. J. Gen. Virol., 78(Pt 10), 2411-8.

19. Mufson, M.A.; Orvell, C.; Rafnar, B.; Norrby, E. (1985). Two distinct subtypes of human respiratory syncytial virus. J. Gen. Virol., 66(Pt 10), 2111-24

20. Roca, A.; Loscertales, M-P.; Quinto, L.; Pérez-Brena, P.; Vaz, N.; Alonso, P-L.; Saiz, J-C. (2001). Genetic variability among group A and $\mathrm{B}$ respiratory syncytial viruses in Mozambique: identification of a new cluster of group B isolates. J. Gen. Virol., 82, 103-111.

21. Peret, T.C.; Hall, C.B.; Schnabel, K.C.; Golub, J.A.; Anderson, L.J. (1998). Circulaton Patterns of Genetically Distinct Group A and B Strains of Human Respiratory Syncytial Virus in a Community. $J$. Gen. Virol., 79, 2221-2229.
22. Peret, T.C.T.; Hall, C.B.; Hammond, G.W.; Piedra, P.A.; Storch, G.A.; Sullender, W.M.; Tsou, C.; Anderson, L.J. (2000). Circulation patterns of group A and B human respiratory syncytial virus genotypes in 5 communities in North America. J. Infect. Dis., 181, 1891-1896.

23. Purcell, K.; Fergie, J. (2004). Driscoll Children's Hospital respiratory syncytial virus database; risk factors, treatment and hospital course in 3308 infants and young children, 1991 to 2002. Pediatr. Infect. Dis. J., 23, 418-23.

24. Sanz, M.C.; Kew, O.M.; Anderson, L.J. (1994). Genetic heterogeneity of the attachment glycoprotein $\mathrm{G}$ among group A respiratory Syncytial viruses. Virus Res., 33(3), 203-17.

25. Scott, P.D.; Ochola, R.; Ngama, M.; Okiro, E.A.; Nokes, D.J.; Medley, G.F.; Cane, P.A. (2004). Molecular epidemiology of respiratory syncytial virus in Kilifi district, Kenya. J. Med. Virol., 74(2), 344-54.

26. Sparer, T.E.; Matthews, S.; Hussell, T.; era, A.J.; Garcia-Barreno, B.; Melero, J.A.; Openshaw, P.J. (1998). Eliminating a region of respiratory syncytial virus attachment protein allows induction of protective immunity without vaccine-enhanced lung eosinophilia. J. Exp. Med., 187(11), 1921-6.

27. Sullender, W.M.; Mufson, M.A.; Andeson, L.J.; Wertz, G.W. (1991). Genetic diversity of the attachment protein of subgroup B respiratory syncytial viruses. J. Virol., 65, 5425-5434.

28. Swofford, D.L. (1998). PAUP* - Phylogenetic Analysis Using Parsimony (*and others methods). Version 4. Sinauer Associates, Sunderland Massachusets.

29. Trento, A.; Galiano, M.; Videla, C.; Carballal, G.; Garcia-Barreno, B.; Melero, J.A.; Palomo, C. (2003). Major changes in the G protein of human respiratory syncytial vírus isolates introduced by a duplication of 60 nucleotides. J. Gen. Virol., 84, 3115-3120.

30. Varga, S.M.; Wissinger, E.L.; Braciale, T.J. (2000). The attachment (G) glycoprotein of respiratory syncytial virus contains a single immunodominant epitope that elicits both Th1 and Th2 CD4+ T cell responses. J. Immunol., 165, 6487-6497.

31. Venter, M.; Madhi, S.A.; Tiemessen, C.T.; Schoub, B.D. (2001). Genetic diversity and molecular epidemiology of respiratory syncytial virus over four consecutive seasons in South Africa: identification of new subgroup A and B genotypes. J. Gen. Virol., 82, 2117-24.

32. Vieira, S.E.; Stewien, K.E.; Queiroz, D.A.O.; Durigon, E.L.; Török, T.J.; Anderson, L.J.; Miyao, C.R.; Hein, N.; Botosso, V.F.; Pahl, M.M.; Gilio, A.E.; Ejzenberg, B.; Okay, Y. (2001). Clinical patterns and seasonal trenes in respiratory syncytial virus hospitalizations in São Paulo, Brazil. Rev. Inst. Med. Trop. S. Paulo., 43(3), 125-131.

33. Yang, Z. (1997). PAML v.13. Phylogenetic analysis by maximum likekihood. Department of Integrative Biology, University of California - Berkeley.

34. Yilmaz, G.; Isik, N.; Kansak, N.; Badur, S.; Ang, O.; Ugur Baysal, S.; Uzel, N. (1999). Detection of respiratory syncytial virus in samples frozen at -20 degrees C. J. Clin. Microbiol., 37(7), 2390.

35. Zelaya, E.A.C.; Petterson, C.A.; Forsgren, M.; Orvell, C.; Strannergard, O. (1994). Respiratory Syncytial Virus Infection in Hospitalized Patients and Healthy Children in El Salvador. Am. J. Trop. Med. Hyg., 51, 577-584.

36. Zheng, H.; Peret, T.C.T.; Randolph, V.B.; Crowley, J.C.; Anderson, L.J. (1996). Strain-specific reverse transcriptase PCR assay: Means to distinguish candidate vaccine from wild-type strain of respiratory syncytial virus. J. Clin. Microbiol., 34(2), 334-337.

37. Zlateva, K.T.; Lemey, P.; Vandamme, A-M.; Van Ranst, M. (2004). Molecular evolution and circulation patterns of human respiratory virus subgroup A: positively selected sites in the attachment $G$ glycoprotein. J. Virol., 78, 5675-4683.

38. Zlateva, K.T.; Lemey, P.; Moës, E.; Vandamme, A-M.; Van Ranst, M. (2005). Genetic variability and molecular evolution of the human respiratory syncytial virus subgroup B attachment G protein. $J$. Virol., 79(14), 9157-67. 